\title{
REAKSI PASAR MODAL DALAM MENYIKAPI PENGUMUMAN KASUS COVID-19 PERDANA DI INDONESIA
}

\author{
Ignatius Lysander \\ Program Studi Magister Manajemen Universitas Tarumanagara \\ ig.lysander@gmail.com \\ Yanuar \\ Program Studi Magister Manajemen Universitas Tarumanagara
}

Masuk : 07-12-2020, revisi : 23-12-2020, diterima untuk diterbitkan : 28-12-2020

\begin{abstract}
This study intends to determine the significance of the Indonesian Capital Market reaction, through average abnormal returns and average trading volume activity in responding to the announcement of the Indonesia Covid-19 first case on March 2, 2020. This research is limited to 45 companies of LQ-45 stock index constituents which are listed on the Indonesia Stock Exchange during the 21 days of the window period. This study reveals an interesting finding that in an increasingly uncertain situation, investors' decisions are mainly based on existing information, and perceptions of that information also vary. The research also found that average trading volume activity does not always differ significantly after the occurrence of an event. The results of this study are authentic in the analyzed event related to the Covid19 pandemic in the context of the Indonesian Capital Market.
\end{abstract}

Keywords: Average Abnormal Return, Average Trading Volume Activity, Covid-19 Pandemic

Abstrak: Penelitian ini hendak menguji signifikansi reaksi pasar modal Indonesia, melalui tingkat pengembalian abnormal rata-rata dan aktivitas volume perdagangan rata-rata dalam menyikapi pengumuman kasus Covid-19 perdana di Indonesia pada tanggal 2 Maret 2020. Penelitian ini dibatasi hanya pada 45 emiten konstituen indeks saham LQ-45 yang tercatat di Bursa Efek Indonesia selama 21 hari periode penelitian. Penelitian mengungkap temuan yang menarik, bahwa dalam situasi yang semakin tidak pasti, keputusan investor sangat ditentukan berdasarkan informasi yang sudah ada dan persepsi terhadap informasi tersebut juga beragam. Penelitian juga menemukan bahwa perbedaan aktivitas volume perdagangan rata-rata tidak selalu signifikan pasca terjadinya suatu peristiwa. Hasil penelitian ini otentik dalam peristiwa yang dianalisis bertalian dengan pandemi Covid-19 dalam konteks pasar modal Indonesia.

Kata Kunci: Tingkat Pengembalian Abnormal Rata-rata, Aktivitas Volume Perdagangan Rata-rata, Pandemi Covid-19

\section{PENDAHULUAN}

Pada tahun 2020, dunia menghadapi tantangan dalam bidang kesehatan dan ekonomi sebagai dampak dari pandemi Covid-19. Virus Covid-19 mulai ditetapkan sebagai pandemi oleh WHO pada tanggal 11 Maret 2020. Sampai dengan 16 Oktober 2020, Worldometer (2020) melaporkan 40,1 juta kasus terkonfirmasi yang tersebar di 217 negara/wilayah, dengan kasus harian mencapai 188 ribu. Dari sisi ekonomi, IMF (2020) memprediksi kontraksi pertumbuhan ekonomi global 5\%, ekonomi Amerika Serikat sebesar 8\% dan ekonomi negara maju Kawasan Eropa seperti Inggris dan Perancis lebih dari 10\%. Dalam 2 tahun mendatang, pandemi akan menggerus output ekonomi dunia yang diprediksi mencapai USD 12 trilyun. Pandemi Covid19 juga berdampak serius bagi perekonomian Indonesia. Capital outflow yang mencapai Rp 159,3 triliun hingga 13 April 2020 telah menggerus kinerja pasar dan depresiasi nilai tukar secara signifikan. Indeks LQ-45 telah menyentuh titik terendah sebesar 567 dengan pelemahan 
sebesar 44,13\% dan Rupiah sempat terdepresiasi ke level tertinggi Rp 16.608/USD menjelang akhir Maret 2020. Fakta tersebut menggambarkan stabilitas perekonomian Indonesia rontok dengan amat cepat pasca pengumuman kasus virus Covid-19 perdana pada awal Maret 2020.

Penelitian dampak pandemi Covid-19 terhadap pasar modal terkini belum banyak dilakukan. Namun, sejumlah penelitian historis telah mengkaji dampak peristiwa biologis, khususnya virus Corona terhadap pasar modal dimana hasilnya relatif inkonsisten. Temuan Chen et al. (2007) bahwa SARS berdampak signifikan justru bertentangan dengan temuan Nippani dan Washer (2004) serta Loh (2006) bahwa SARS tidak berdampak signifikan terhadap kinerja pasar modal, meski cenderung terdevaluasi. Kendati pasar modal Indonesia juga terdampak pandemi, penelitian yang relevan sangat jarang dilakukan. Studi berbagai peristiwa historis juga relatif inkonsisten. Temuan Anwar et al. (2020) bahwa abnormal return tidak signifikan dalam pemilu 2019 bertentangan dengan temuan Wulandari et al. (2017) bahwa abnormal return dalam pemberlakuan UU Pengampunan Pajak signifikan.

Berbagai inkonsistensi hasil penelitian di atas membuka ruang bagi studi lanjutan reaksi pasar modal dalam menyikapi suatu peristiwa. Studi akan difokuskan pada reaksi pasar modal di sekitar pengumuman kasus Covid-19 perdana karena penelitian sejenis yang relevan masih jarang dilakukan. Minat studi diperkuat dengan data indeks LQ-45 yang merosot 2,3\% pada tanggal pengumuman sehingga peristiwa ini relevan untuk diteliti.

Pasar modal Indonesia menarik untuk diteliti. Indonesia adalah negara terbesar dengan pasar domestik yang luas dan pasar modalnya salah satu dari 3 pasar modal teratas di kawasan Asia Tenggara (Imamah et al., 2019). Indonesia diprediksi menempati peringkat 5 kekuatan ekonomi dunia pada tahun 2024. Sharma et al. (2019) mengemukakan bahwa pasar modal Indonesia dalam tahap berkembang, sehingga relevan sebagai subjek penelitian studi peristiwa.

\section{Tujuan Penelitian}

Penelitian ini bertujuan untuk menganalisis reaksi pasar modal Indonesia dalam menyikapi pengumuman kasus Covid-19 perdana di Indonesia. Reaksi pasar modal akan direpresentasikan melalui perbedaan indikator average abnormal return dan average trading volume activity antara sebelum, saat dan setelah pengumuman tersebut secara signifikan.

\section{TINJAUAN PUSTAKA}

\section{Pengaruh Pengumuman Kasus Covid-19 Perdana terhadap Tingkat Pengembalian Abnormal Rata-rata}

Berdasarkan teori pensinyalan, interpretasi investor terhadap suatu informasi akan bergantung pada nilai perekonomiannya (Dwianto \& Yulita, 2020, p. 26). Jika investor mempersepsikan informasi tersebut buruk, maka reaksi pasar akan direfleksikan melalui penurunan harga sekuritas karena investor yakin bahwa peristiwa tersebut membahayakan nilai perusahaan. Ashraf (2020) mengemukakan bahwa harga saham bereaksi kuat saat kasus Covid19 perdana terkonfirmasi dan pertumbuhan kasus positif pasca pengumuman, tetapi justru tidak bereaksi kuat ketika kasus meninggal terkonfirmasi di kemudian hari. Ini membuktikan bahwa investor yang canggih telah memperkirakan dampak negatif dari pandemi Covid-19 terhadap nilai perusahaan. Sun et al. (2021) mendukung temuan ini bahwa pandemi Covid-19 telah menyebabkan sentimen negatif yang meluas hingga meningkatkan gejolak pasar. Kusnandar dan Bintari (2020) menemukan bahwa investor merespons negatif pengumuman perubahan waktu perdagangan bursa efek karena abnormal return cenderung negatif yang bersumber dari aksi jual investor secara masif. Dari sebab itu, Peneliti mengajukan tiga hipotesis penelitian sebagai berikut:

$\mathrm{Ha}_{1}$ : Average abnormal return antara sebelum dan saat pengumuman kasus Covid-19 perdana di Indonesia berbeda secara signifikan.

$\mathrm{Ha}_{2}$ : Average abnormal return antara setelah dan saat pengumuman kasus Covid-19 perdana di Indonesia berbeda secara signifikan.

$\mathrm{Ha}_{3} \quad$ : Average abnormal return antara sebelum dan setelah pengumuman kasus Covid-19 perdana di Indonesia berbeda secara signifikan. 


\section{Pengaruh Pengumuman Kasus Covid-19 Perdana di Indonesia terhadap Aktivitas Volume Perdagangan Rata-rata}

Signifikansi aktivitas volume perdagangan rata-rata menunjukkan bahwa peristiwa mengandung informasi yang relevan, terlepas mengandung persepsi baik atau buruk, sehingga menggerakkan aksi jual atau beli saham dalam jumlah yang signifikan. Jika investor menganggap pandemi Covid-19 akan mengancam kinerja pasar dalam jangka panjang, maka investor akan semakin gencar melancarkan aksi jual. Penelitian Chiah dan Zhong (2020) menemukan bahwa perdagangan saham semakin intensif selama pandemi Covid-19. Hasil ini didukung dengan temuan Subrata dan Werastuti (2020) bahwa investor mempersepsikan penetapan status darurat Covid-19 sebagai kabar buruk yang diidentifikasi melalui peningkatan volume transaksi pasca pengumuman dari aksi jual yang masif. Dengan demikian, Peneliti mengajukan tiga hipotesis penelitian sebagai berikut:

$\mathrm{Ha}_{4}$ : Average trading volume activity antara sebelum dan saat pengumuman kasus Covid-19 perdana di Indonesia berbeda secara signifikan.

$\mathrm{Ha}_{5} \quad$ : Average trading volume activity antara setelah dan saat pengumuman kasus Covid-19 perdana di Indonesia berbeda secara signifikan.

$\mathrm{Ha}_{6} \quad$ : Average trading volume activity antara sebelum dan setelah pengumuman kasus Covid-19 perdana di Indonesia berbeda secara signifikan.

\section{METODOLOGI PENELITIAN}

Penelitian ini merupakan studi peristiwa untuk menguji reaksi pasar modal dalam menyikapi pengumuman kasus Covid-19 perdana di Indonesia pada tanggal 2 Maret 2020. Peneliti menetapkan periode jendela selama 21 hari perdagangan efektif, yaitu 10 hari sebelum dan 10 hari setelah tanggal peristiwa. Penelitian ini hanya akan difokuskan pada seluruh emiten anggota indeks LQ-45 yang tercatat di Bursa Efek Indonesia selama periode penelitian saja.

Penelitian ini melibatkan dua variabel yang merepresentasikan signifikansi reaksi pasar modal, yaitu tingkat pengembalian abnormal rata-rata dan aktivitas volume perdagangan ratarata. Definisi operasional dan pengukuran tiap-tiap variabel penelitian adalah sebagai berikut:

\section{Tabel 1}

Definisi Operasional dan Pengukuran Variabel Penelitian

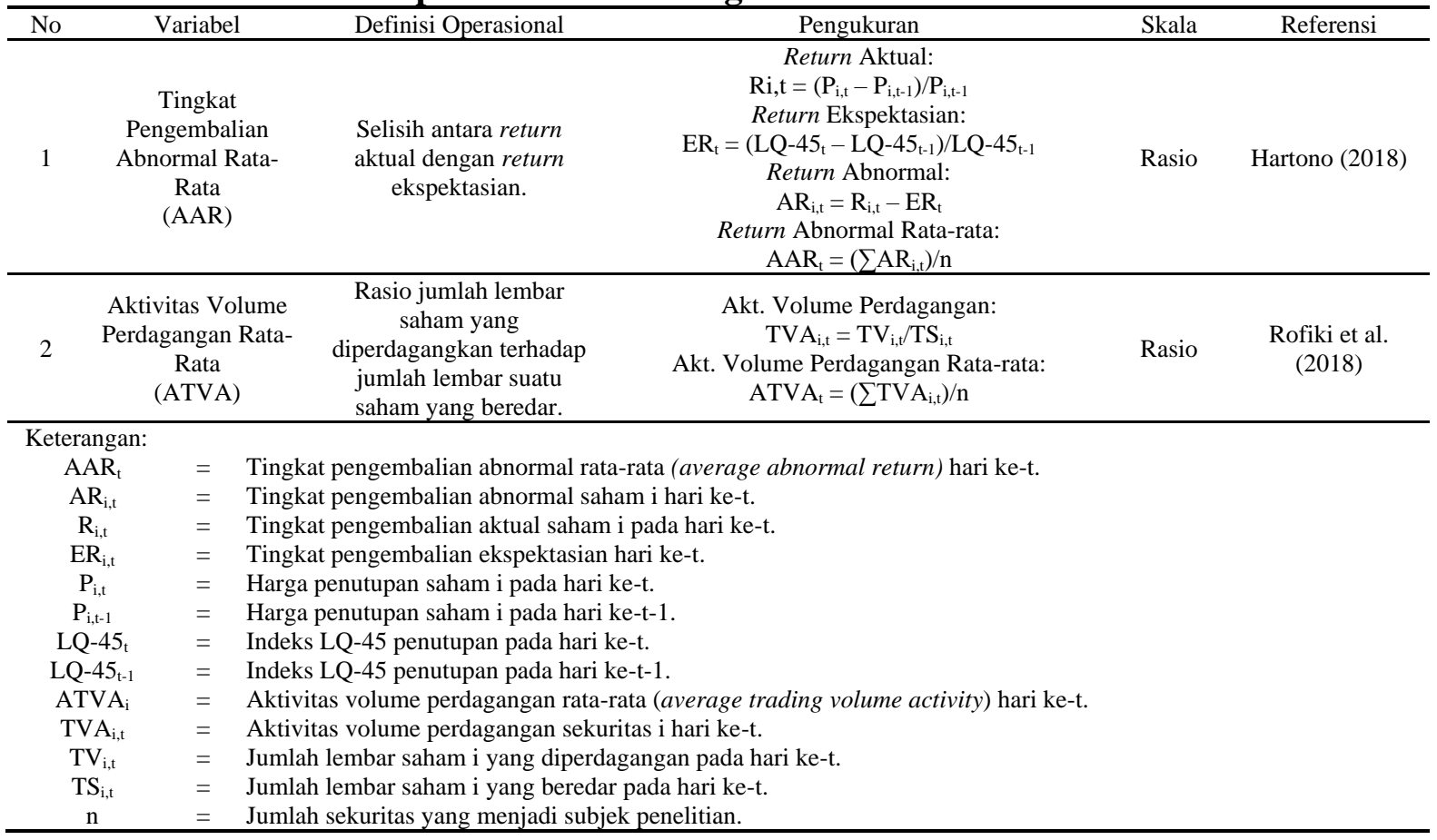

Peneliti terlebih dahulu menguji normalitas data-data penelitian dengan metode onesample Kolmogorov-Smirnov pada taraf signifikansi $(\alpha)$ sebesar 5\%. Jika nilai probabilitas 
signifikansi lebih besar dari 0,05, maka data-data penelitian berdistribusi normal. Jika uji normalitas terpenuhi, maka Peneliti menggunakan metode statistik parametrik sebagai berikut:

1. Uji t Sampel Tunggal: Peneliti menggunakan uji t sampel tunggal pada taraf signifikansi (a) sebesar 5\% untuk melakukan pengujian hipotesis penelitian $\mathrm{Ha}_{1}, \mathrm{Ha}_{2}, \mathrm{Ha}_{4}$, dan $\mathrm{Ha} 5$. Jika nilai $p$-value lebih kecil atau sama dengan 0,05 , maka hipotesis alternatif tidak ditolak.

2. Uji t Sampel Berpasangan: Peneliti akan menggunakan uji t sampel berpasangan pada taraf signifikansi $(\alpha)$ sebesar $5 \%$ untuk melakukan pengujian hipotesis penelitian $\mathrm{Ha}$ dan Ha6. Jika nilai $p$-value lebih kecil atau sama dengan 0,05 , maka hipotesis alternatif tidak ditolak.

Jika uji normalitas tidak terpenuhi, maka Peneliti menggunakan uji peringkat bertanda Wilcoxon (Wilcoxon Signed-Rank Test) pada taraf signifikansi $(\alpha)$ sebesar 5\%. Jika nilai $p$ value lebih kecil atau sama dengan 0,05, maka hipotesis alternatif tidak ditolak.

\section{HASIL DAN SIMPULAN}

Tabel 2

Hasil Pengujian Asumsi Normalitas

\begin{tabular}{|c|c|c|c|c|}
\hline & AAR Sebelum & AAR Setelah & ATVA Sebelum & ATVA Setelah \\
\hline N & 10 & 10 & 10 & 10 \\
\hline Asymp. Sig. (2-tailed) & 0,200 & 0,200 & 0,200 & 0,200 \\
\hline
\end{tabular}

Sumber: Olahan Data Peneliti

Nilai probabilitas signifikansi Asymp. Sig. (2-tailed) keempat data penelitian adalah sebesar 0,200 dan lebih besar dari 0,05. Dengan demikian, data penelitian telah memenuhi asumsi normalitas dan dapat diuji dengan menggunakan metode statistik parametrik.

\section{Tabel 3}

Hasil Pengujian Hipotesis dengan Uji t Sampel Tunggal

\begin{tabular}{|c|c|c|c|}
\hline \multicolumn{2}{|c|}{$\mathbf{H}_{\mathbf{1}}$} & \multicolumn{2}{c|}{$\mathbf{H}_{\mathbf{2}}$} \\
\hline \multicolumn{2}{|c|}{ AAR Sebelum-Saat } & \multicolumn{2}{c|}{ AAR Setelah-Saat } \\
\hline Periode & Sig & Sig & Periode \\
\hline $\mathrm{t}_{-}$ & $0,006^{*}$ & 0,199 & $\mathrm{t}_{+1}$ \\
$\mathrm{t}-2$ & 0,300 & 0,109 & $\mathrm{t}_{+2}$ \\
$\mathrm{t}-3$ & $0,000^{*}$ & $0,000^{*}$ & $\mathrm{t}_{+3}$ \\
$\mathrm{t}-4$ & 0,090 & 0,079 & $\mathrm{t}_{+4}$ \\
$\mathrm{t}-5$ & $0,000^{*}$ & $0,000^{*}$ & $\mathrm{t}_{+5}$ \\
$\mathrm{t}-6$ & $0,000^{*}$ & $0,032^{*}$ & $\mathrm{t}_{+6}$ \\
$\mathrm{t}-7$ & $0,003^{*}$ & $0,000^{*}$ & $\mathrm{t}_{+7}$ \\
$\mathrm{t}_{-}$ & $0,000^{*}$ & $0,000^{*}$ & $\mathrm{t}_{+8}$ \\
$\mathrm{t}_{-9}$ & $0,025^{*}$ & $0,012^{*}$ & $\mathrm{t}_{+9}$ \\
$\mathrm{t}_{-10}$ & 0,589 & $0,000^{*}$ & $\mathrm{t}_{+10}$ \\
\hline
\end{tabular}

Sumber: Olahan Data Peneliti

\begin{tabular}{|c|c|c|c|}
\hline \multicolumn{2}{|c|}{$\mathbf{H}_{\mathbf{4}}$} & \multicolumn{2}{|c|}{$\mathbf{H}_{\mathbf{5}}$} \\
\hline \multicolumn{2}{|c|}{ ATVA Sebelum-Saat } & \multicolumn{2}{c|}{ ATVA Setelah-Saat } \\
\hline Periode & Sig & Sig & Periode \\
\hline $\mathrm{t}_{-1}$ & $0,049^{*}$ & 0,854 & $\mathrm{t}_{+1}$ \\
$\mathrm{t}-2$ & 0,449 & 0,984 & $\mathrm{t}_{+2}$ \\
$\mathrm{t}-3$ & $0,014^{*}$ & 0,488 & $\mathrm{t}_{+3}$ \\
$\mathrm{t}-4$ & $0,006^{*}$ & $0,003^{*}$ & $\mathrm{t}_{+4}$ \\
$\mathrm{t}-5$ & 0,783 & 0,536 & $\mathrm{t}_{+5}$ \\
$\mathrm{t}-6$ & 0,393 & 0,217 & $\mathrm{t}_{+6}$ \\
$\mathrm{t}-7$ & $0,007^{*}$ & 0,258 & $\mathrm{t}_{+7}$ \\
$\mathrm{t}_{-8}$ & $0,007^{*}$ & 0,365 & $\mathrm{t}_{+8}$ \\
$\mathrm{t}-9$ & 0,145 & $0,003^{*}$ & $\mathrm{t}_{+9}$ \\
$\mathrm{t}_{-10}$ & $0,000^{*}$ & $0,018^{*}$ & $\mathrm{t}_{+10}$ \\
\hline
\end{tabular}

* Signifikan

AAR antara sebelum dan saat, maupun setelah dan saat tanggal peristiwa, berbeda secara signifikan selama 7 dari 10 hari. Dengan demikian, meski tidak penuh, pengujian $\mathrm{Ha}_{1}$ dan $\mathrm{Ha}_{2}$ tidak ditolak. Hasil penelitian sejalan dengan temuan Susanti (2015), Wardhani dan Djazuli (2013), tetapi bertentangan dengan hasil penelitian Widodo dan Laila (2016). ATVA sebelum dan saat tanggal peristiwa berbeda secara signifikan selama 6 dari 10 hari. Dengan demikian, meski tidak penuh, pengujian Ha4 tidak ditolak. Hasil penelitian sejalan dengan temuan Susanti (2015), Wardhani dan Djazuli (2013). ATVA setelah dan saat tanggal peristiwa berbeda secara signifikan hanya selama 3 dari 10 hari. Dengan demikian, meski tidak penuh, pengujian Ha5 ditolak. Hasil penelitian justru bertentangan dengan temuan Susanti (2015), Wardhani dan Djazuli (2013). Peneliti tidak menemukan penelitian historis yang mendukung sehingga temuan ini telah berkontribusi secara empiris bahwa ATVA tidak selalu signifikan pasca keterjadian suatu peristiwa.

\section{Tabel 4}

Hasil Pengujian Hipotesis dengan Uji t Sampel Berpasangan

\begin{tabular}{|c|c|c|c|}
\hline Hipotesis & Variabel & Sig. (2-tailed) & Simpulan \\
\hline $\mathrm{H}_{3}$ & AAR Sebelum-Setelah & 0,085 & Tidak Signifikan \\
$\mathrm{H}_{6}$ & ATVA Sebelum-Setelah & 0,000 & Signifikan \\
\hline
\end{tabular}

Sumber: Olahan Data Peneliti 
Perbedaan AAR antara sebelum dan setelah pengumuman yang tidak signifikan mungkin disebabkan karena investor memandang pengumuman tersebut tinggal menunggu waktu sehingga tidak mengejutkan. Perilaku konservatif investor diperkuat dengan sikap Pemerintah yang kerap kontraproduktif dengan harapan masyarakat dalam menyikapi ancaman Covid-19. Hasil penelitian ini inkonsisten dengan hasil pengujian $\mathrm{Ha}_{1}$ dan $\mathrm{Ha} 2$. Eksistensi AAR harian lazim dalam pola ambil untung dengan memanfaatkan konservatisme investor, yang notabene telah terjadi sebelum peristiwa. Dari sebab itu, pengumuman tersebut tidak cukup kuat menggerakan reaksi pasar yang dapat mempertahankan AAR dalam jangka panjang. Temuan bersesuaian dengan hasil penelitian Anwar et al. (2020), tetapi bertentangan dengan hasil penelitian Wulandari et al. (2017).

Hasil pengujian perbedaan ATVA antara sebelum dan setelah pengumuman yang signifikan justru inkonsisten dengan hasil pengujian На3. Kuat dugaan, pelaku pasar modal memberikan interpretasi yang beragam terhadap pengumuman tersebut. Dalam situasi pasar keuangan yang kian tidak pasti, pengumuman tersebut dapat dimaknai sebagai ancaman atau kesempatan bagi para investor untuk mengambil AAR dalam jangka pendek, meskipun perilaku investor cenderung lebih konservatif. Dengan demikian, peningkatan ATVA tidak serta merta diikuti dengan penciptaan AAR yang dapat dinikmati oleh investor dalam jangka panjang. Hasil penelitian bersesuaian dengan temuan Akbar et al. (2019), tetapi bertentangan dengan hasil penelitian Vahini dan Putra (2015).

Berdasarkan hasil analisis dan pembahasan yang telah dilakukan, maka penelitian ini menghasilkan sejumlah simpulan sebagai berikut: (1) Average abnormal return, baik antara sebelum-saat, maupun setelah-saat peristiwa berbeda secara signifikan, tetapi antara sebelumsetelah peristiwa tidak berbeda secara signifikan; (2) Average trading volume activity antara sebelum dan saat peristiwa tidak berbeda secara signifikan, tetapi berbeda secara signifikan antara setelah dan saat peristiwa. Average trading volume activity antara sebelum dan setelah peristiwa berbeda secara signifikan.

Implikasi penelitian mengidentifikasi gejolak pasar modal harian yang menunjukkan bahwa kelompok investor yang melakukan trading jangka pendek relatif cukup besar di Indonesia, sehingga selain perlu "melek" dalam literasi keuangan, sebaiknya investor tidak terburu-buru bertindak semata berdasarkan arus utama yang kadangkala kurang rasional. Hal lain, hasil penelitian membuktikan meski pasar modal Indonesia relatif efisien, tetapi rentan dipengaruhi perkembangan antarwaktu yang singkat. Dari sebab itu, menjaga kepercayaan pelaku pasar sangat penting untuk menyelamatkan kinerja pasar modal dalam situasi krisis.

\section{DAFTAR PUSTAKA}

Akbar, E. P., Saerang, I. S., \& Maramis, J. B. (2019). Reaksi pasar modal terhadap pengumuman kemenangan Presiden Joko Widodo berdasarkan keputusan KPU Pemilu periode 2019-2024 (Studi pada perusahaan BUMN yang terdaftar di BEI). JMBI UNSRAT (Jurnal Ilmiah Manajemen Bisnis Dan Inovasi Universitas Sam Ratulangi)., 6(2), 123-131. https://doi.org/10.35794/jmbi.v6i2.26169

Anwar, J., Diana, N., \& Mawardi, M. C. (2020). Pengaruh peristiwa politik tahun 2019 (Pemilu Presiden dan pengumuman susunan kabinet) terhadap saham sektor industri di Bursa Efek Indonesia. Jurnal Ilmiah Riset Akuntansi, 9(4), 83-96. http://www.riset.unisma.ac.id/index.php/jra/article/view/6187

Ashraf, B. N. (2020). Stock markets' reaction to COVID-19: Cases or fatalities? Research in International Business and Finance, 54, 1-18. https://doi.org/10.1016/j.ribaf.2020.101249

Chen, M. H., Jang, S. C. (Shawn), \& Kim, W. G. (2007). The impact of the SARS outbreak on Taiwanese hotel stock performance: An event-study approach. International Journal of Hospitality Management, 26(1), 200-212. https://doi.org/10.1016/j.ijhm.2005.11.004

Chiah, M., \& Zhong, A. (2020). Trading from home: The impact of COVID-19 on trading volume around the world. Finance Research Letters, 37, 1-17. https://doi.org/10.1016/j.frl.2020.101784 
Dwianto, N. A., \& Yulita, I. K. (2020). Reaksi pasar modal Indonesia terhadap peluncuran rudal Korea Utara. Exero: Journal of Research in Business and Economics, 2(1), 22-40. https://doi.org/10.24071/exero.v2i1.2059

Hartono, J. (2018). Studi peristiwa: Menguji reaksi pasar modal akibat suatu peristiwa. BPFEYogyakarta.

Imamah, N., Lin, T. J., Suhadak, Handayani, S. R., \& Hung, J. H. (2019). Islamic law, corporate governance, growth opportunities and dividend policy in Indonesia stock market. Pacific Basin Finance Journal, 55, 110-126. https://doi.org/10.1016/j.pacfin.2019.03.008

International Monetary Fund. (2020). World economic outlook update, June 2020: A crisis like no other, an uncertain recovery. IMF.

https://www.imf.org/en/Publications/WEO/Issues/2020/06/24/WEOUpdateJune2020

Kusnandar, D. L., \& Bintari, V. I. (2020). Perbandingan abnormal return saham sebelum dan sesudah perubahan waktu perdagangan selama pandemi Covid-19. Jurnal Pasar Modal Dan Bisnis, 2(2), 195-202. https://doi.org/10.37194/jpmb.v2i2.49

Loh, E. (2006). The impact of SARS on the performance and risk profile of airline stocks. International Journal of Transport Economics, 33(3), 401-422. https://doi.org/10.1400/55242

Nippani, S., \& Washer, K. M. (2004). SARS: A non-event for affected countries' stock markets? Applied Financial Economics, 14(15), 1105-1110. https://doi.org/10.1080/0960310042000310579

Rofiki, D., Topowijono, \& Nurlaily, F. (2018). Reaksi pasar modal Indonesia akibat peristiwa pemilihan Gubernur DKI Jakarta Putaran II 2017 (Event study pada saham perusahaan yang terdaftar di Indeks LQ45 periode Februari-Juli 2017). Jurnal Administrasi Bisnis (JAB), 62(2), 185-193. http://administrasibisnis.studentjournal.ub.ac.id/index.php/jab/article/view/2689

Sharma, S. S., Narayan, P. K., Thuraisamy, K., \& Laila, N. (2019). Is Indonesia's stock market different when it comes to predictability? Emerging Markets Review, 40, 1-11. https://doi.org/10.1016/j.ememar.2019.100623

Subrata, I. K., \& Werastuti, D. N. S. (2020). Analisis reaksi pasar pada penetapan status darurat global ke level tertinggi terkait virus Corona oleh WHO (World Health Organization) pada Bursa Efek Indonesia. Jurnal Ilmiah Mahasiswa Akuntansi, 11(2), 169-177. https://doi.org/10.23887/jimat.v11i2.25161

Sun, Y., Wu, M., Zeng, X., \& Peng, Z. (2021). The impact of COVID-19 on the Chinese stock market: Sentimental or substantial? Finance Research Letters, 38, 1-18. https://doi.org/10.1016/j.frl.2020.101838

Susanti, A. (2015). Analisis pengaruh kemenangan pasangan Joko Widodo-Jusuf Kalla dalam Pilpres 2014 terhadap abnormal return dan trading volume activity pada kelompok saham Indeks LQ45 [Universitas Negeri Yogyakarta]. http://eprints.uny.ac.id/24689/1/SKRIPSI.pdf

Vahini, Y. P., \& Putra, N. W. A. (2015). Event study: Analisis reaksi investor pada publikasi laporan keuangan tahunan. E-Jurnal Akuntansi, 13(2), 387-404. https://ojs.unud.ac.id/index.php/Akuntansi/article/view/11520/11014

Wardhani, L. S., \& Djazuli, A. (2013). Reaksi pasar modal Indonesia terhadap peristiwa pemilihan Gubernur DKI Jakarta Putaran II 2012 (Event study pada saham anggota Indeks Kompas 100). Jurnal Ilmiah Mahasiswa FEB, 1(1), 1-13. https://jimfeb.ub.ac.id/index.php/jimfeb/article/view/171/134

Widodo, A., \& Laila, N. (2016). Reaksi pasar atas pengumuman dividen (Studi pada emiten yang terdaftar di Jakarta Islamic Index). Jurnal Ekonomi Syariah Teori Dan Terapan, 3(2), 85-98. https://doi.org/10.20473/vol3iss20162pp85-98

Worldometer. (2020). COVID live - Coronavirus statistics. Worldometer. https://www.worldometers.info/coronavirus/

Wulandari, I. G. A. A. D., Wahyuni, M. A., \& Sujana, E. (2017). Reaksi investor dalam pasar modal terhadap Undang-Undang Tax Amnesty (Event study pada perusahaan yang terdaftar dalam LQ45 di Bursa Efek Indonesia). E-Journal S1 Ak Universitas Pendidikan Ganesha, 7(1), 1-10. https://doi.org/10.23887/jimat.v7i1.9504 